\title{
Zircon U-Pb geochronology, Nd-Sr (whole-mineral) isotopic and geochemical characterization of mafic granulites from the Central Indian Tectonic Zone: Age constraints on crustal evolution for central Indian
}

\section{Shield}

\author{
MERAJ ALAM ${ }^{1}$, TALAT AHMAD ${ }^{2}$, MUKESH KUMAR \\ MISHRA $^{3}$ AND TATIANA KAULINA ${ }^{4}$ \\ ${ }^{1}$ Indira Gandhi National Tribal University \\ ${ }^{2}$ University of Kashmir \\ ${ }^{3}$ Geological Survey of India \\ ${ }^{4}$ GI KSC RAS \\ Presenting Author: merajdu@gmail.com
}

The studies of $\mathrm{U}-\mathrm{Pb}$ zircon geochronology, Nd-Sr isotopic, and geochemical analyses were carried out for mafic granulite from the northern margin of the Central Indian Shear Zone (CISZ) within the Central Indian Tectonic Zone (CITZ) to explore the geochronological and petrological constraints on Precambrian crustal evolution. The geochemical plots and trends define a tholeiitic character with basalt to alkali basaltic composition. However, major element variation characteristics suggest a primary magmatic differentiation of the parental melt/igneous protolith of these mafic granulites. Moreover, studied rocks are classified as tholeiitic magma series with derivation from a diverse enriched lithospheric mantle source. Primitive mantle normalized multi-element diagram express slight depletion in large Ion-lithophile elements (LILE) with negative anomalies in $\mathrm{Rb}, \mathrm{K}, \mathrm{Th}, \mathrm{Nb}, \mathrm{Sr}, \mathrm{P}, \mathrm{Zr}$, and $\mathrm{Ti}$, but positive in $\mathrm{Ba}, \mathrm{U}, \mathrm{Pb}$, and $\mathrm{Nd}$. Observed anomalies are majorly attributed to plagioclase, Ti-magnetite, apatite fractionation; however, the prominent positive $\mathrm{Pb}$ anomaly probably suggests a crustal influence. Minerals plagioclase, apatite, and amphibole exhibit an Sm-Nd mineral isochron age of $1014 \pm 34 \mathrm{Ma}$ (MSWD=1.4); however, amphibole and garnet define an age of $1030 \pm 8.8$ Ma. Furthermore, apatite, clinopyroxene, amphibole defines an Rb-Sr mineral isochron age of $1369 \pm 84 \mathrm{Ma}$ (MSWD=0.74). These obtained isochron ages are probably suggested to the poly-phase retrograde metamorphism which was locally occurred within the CITZ. U-Pb zircon age of $1564 \pm 8 \mathrm{Ma}$ indicates granulite metamorphism and is related to the Tirodi gneiss generation. Geochemical signatures are suggested that the protolith of these mafic granulites have probably undergone MORB and rift-related settings which is probably inferred to the Columbia supercontinent. 